Article

\title{
An Innovative Land Suitability Method to Assess the Potential for the Introduction of a New Crop at a Regional Level
}

\author{
Elisa Marraccini ${ }^{1, *(\mathbb{D}}$, Alicia Ayerdi Gotor ${ }^{2} \mathbb{D}$, Olivier Scheurer ${ }^{3}$ and Christine Leclercq ${ }^{1}$ \\ 1 UniLaSalle, INTERACT, UP 2018.C102, 60026 Beauvais, France; christine.leclercq@unilasalle.fr \\ 2 UniLaSalle, AGHYLE, UP 2018.C101,60026 Beauvais, France; alicia.ayerdi-gotor@unilasalle.fr \\ 3 UniLaSalle, 60026 Beauvais, France; olivier.scheurer@unilasalle.fr \\ * Correspondence: elisa.marraccini@unilasalle.fr; Tel.: +33-0344-06-2525
}

Received: 17 January 2020; Accepted: 25 February 2020; Published: 2 March 2020

check for updates

\begin{abstract}
Although crop diversification is one of the main strategy of agroecological transition, a major obstacle is the lack of local references regarding new crops. Land suitability methods can provide a rapid screening of crop suitability in a region. However, mainstream methods are mainly based on assessing soil and climate suitability, whereas it is fundamental to know where and how a new crop can be introduced into existing crop rotations and whether this introduction would be profitable. Our method based on recent advances in the characterization of cropping systems at the regional level can be exploited to evaluate: (1) the yield potential of the new crop, (2) the potential of this new crop being successfully introduced into ongoing crop rotations; (3) the economic benefits of such an introduction. The method was tested for the possible introduction of new soybean varieties in northern France. The method developed has relevance beyond the case study. Our method could also be easily adapted to rapidly assess the potential for introducing new crops in cases where there climate database, soil map information and a Land Parcel Identification System are available.
\end{abstract}

Keywords: land suitability; crop spatial allocation; LPIS; STICS; soybean

\section{Introduction}

Diversification is a key agronomic strategy to reduce the impacts of intensive arable cropping systems. Crop diversification is also one of the main principles of sustainable farming systems such as agroecology, organic farming and conservation agriculture. Diversification refers to an increase in the number of cultivars or crops in the crop rotation or in the increase in the number of cover crops [1]. Legumes or other crops have been investigated in terms of diversification potential [2]. The main benefits of crop diversification include, for example, an increase in yield stability, a reduction in pesticide use, and a decrease in chemical fertilizers because of the internal recycling of nutrients and of nitrogen inputs even in the absence of legume crops [3]. The expected decrease in inputs, e.g., mineral fertilizers and pesticides, also lowers the costs, and may also have a positive impact on farm income [4].

The Common European Agricultural Policies are promoting crop diversification, by, for example, "greening" farms with over 10 ha of arable lands and regulating both the minimum number of crops and the surface of the main crops in the Usable Agricultural Area of the farm [5]. However, in a recent paper, Louhichi et al. [6] concluded that the impact of this policy both on land use reallocation and on farm income of this policy remained rather small at the EU level. In France, Meynard et al. [7] showed that the obstacles for crop diversification in 12 minor crops are linked to the difficult coordination between demand and supply, to the lack of technical references, and to the slower genetic progress compared to major crops. 
In order to advise local farmers on the feasibility of a crop, agricultural actors promoting crop diversification need information on agronomic and economic references on new crop performance. However, there is limited information on how such references can be created in areas where a crop has not been cultivated before. In addition, cooperatives and companies need to estimate if the new crop could reach the minimum area required to make it economically advantageous to harvest it. How can these references be created in areas where the crops have not already been cultivated? Options such as field trials need several years and several trial locations in order to be able to provide references on yield performance or yield gap. In addition to classical agronomic trials, other mixed methods demonstrated that including on-farm trials and participatory crop design may also contribute to the creation of local references on diversification crops [8]. Alternatively, land suitability methods can be conducted as ex-ante assessments based on the crop's physiological needs and the bio-physical characteristics of the area. These land suitability methods have mainly been developed by soil scientists in the framework of land evaluation methods [9]. They are also developed by ecologists under the ecological niche theory in order to predict the potential distribution of species in a given area [10]. In agronomy, four main land suitability approaches have been developed in the literature. Firstly, a classical land suitability approach that locates suitable areas for a given crop mainly by making use of agro-climatic, soil quality and land use data according to the crop requirements (e.g., [11], on land suitability for palm oil in Ghana). Secondly, an approach that is more yield-based and combines interpolations of climatic, soil quality and field trial results on crop yields (e.g., [12] on potato suitability in Ecuador). Thirdly, an approach that uses experimental field trials, often located in several agro-climatic areas (e.g., [13] on the suitability of wheat varieties in Germany). Lastly, an approach that assesses the future land suitability under climate change conditions by modifying climatic or agronomic parameters following climatic scenarios (e.g., $[14,15])$.

These approaches are usually based on previous experimental or field/farm data [16], on common crops outside the current grown area [17] or on crops already cultivated that need to be adapted to different purposes such as biomass crops [18]. They are all rather limited when faced with no or poor local agronomic references.

Ziadat and Sultan [19] argued that the main limitation of these classical land suitability approaches is also due to the lack of information on farmers' practices, which affects the reliability of the results. By comparing classical land suitability maps and on-farm land use and practices for drip-irrigated trees, these authors revised their land suitability model, which enabled almost $20 \%$ of the investigated area to be allocated to a new suitability class. Finally, the validation of the results of these land suitability studies can be limited by the lack of data. In such cases, Debolini, et al. [20] proposed an alternative spatially-explicit method to validate classical land suitability approaches. Their approach is based on mapping the local spatial knowledge on suitable crop areas and types of services provided to farmers by collective structures, e.g., co-operatives or farmers' associations. This method assumes that there is already existing knowledge on the potential for different crops in the region.

The state of the art on land suitability has highlighted two general trends. Firstly, because of a general trend in the demand for crop diversification, there is a need for methods that can provide information on new crops. Secondly, the mainstream land suitability methods are commonly limited to a bio-physical potential without providing agricultural actors with the information needed to make decision, such as whether to introduce new crops in existing crop rotations from an agronomic (where and how to insert the studied crop) or whether the introduction will be economically sound for the farmer. Both these questions are linked. They require a shift from the land use to the cropping system level where crop management and crop rotation decisions are implemented [21]. Examples of these decisions in arable systems include the sowing date or harvest date, and the effect of a crop on the following crop or the return period. Recent literature on the regional spatialisation of cropping systems and on the dynamics of farming systems at landscape and territorial levels have provided insights into the application of such agronomic decisions [22-27]. These new approaches could help to improve 
land suitability studies based on the bio-physical characteristics and on the diversity of crop rotations and cropping systems at the regional level.

In this context, the aim of this work is to develop an innovative method to assess the potential for the introduction of new crops in arable crop rotations, in regions that lack agronomic references, which is an obstacle to the diversification of crop rotations. Our test case was the introduction of soybean in crop rotations in northern France. The remainder of the paper is organized as follows. Section 2 presents: the materials and methods plus the case study. Section 3 presents: the results of the implementation of the method in relation to the introduction of soybean in northern France. Finally, Section 4 discusses the results obtained and possible limitations, the barriers to the introduction of new crops and areas for future application of the method.

\section{Materials and Methods}

\subsection{Overall Method}

The main input for assessing the area suitable for a new crop is the region agricultural area. Non-agricultural areas are either urbanized or have a natural cover that indicates poor suitability and were thus not considered.

Three subsequent steps enabled to identify areas potentially suitable for the new crop: (1) biophysically suitable areas, combining suitability of both climate and soil according to new crop requirements as done in the more classical land suitability approaches; (2) agronomically suitable areas, which combine biophysical suitability and suitable crop rotations for the new crop identified through crop rotation modelling coupled with general agronomic as well as the decision-rules of local experts; and finally (3) economically suitable areas, derived from the difference between the modelled crop rotation gross margins of the ongoing and the re-designed crop rotation including the new crop. The overall method is presented in Figure 1.

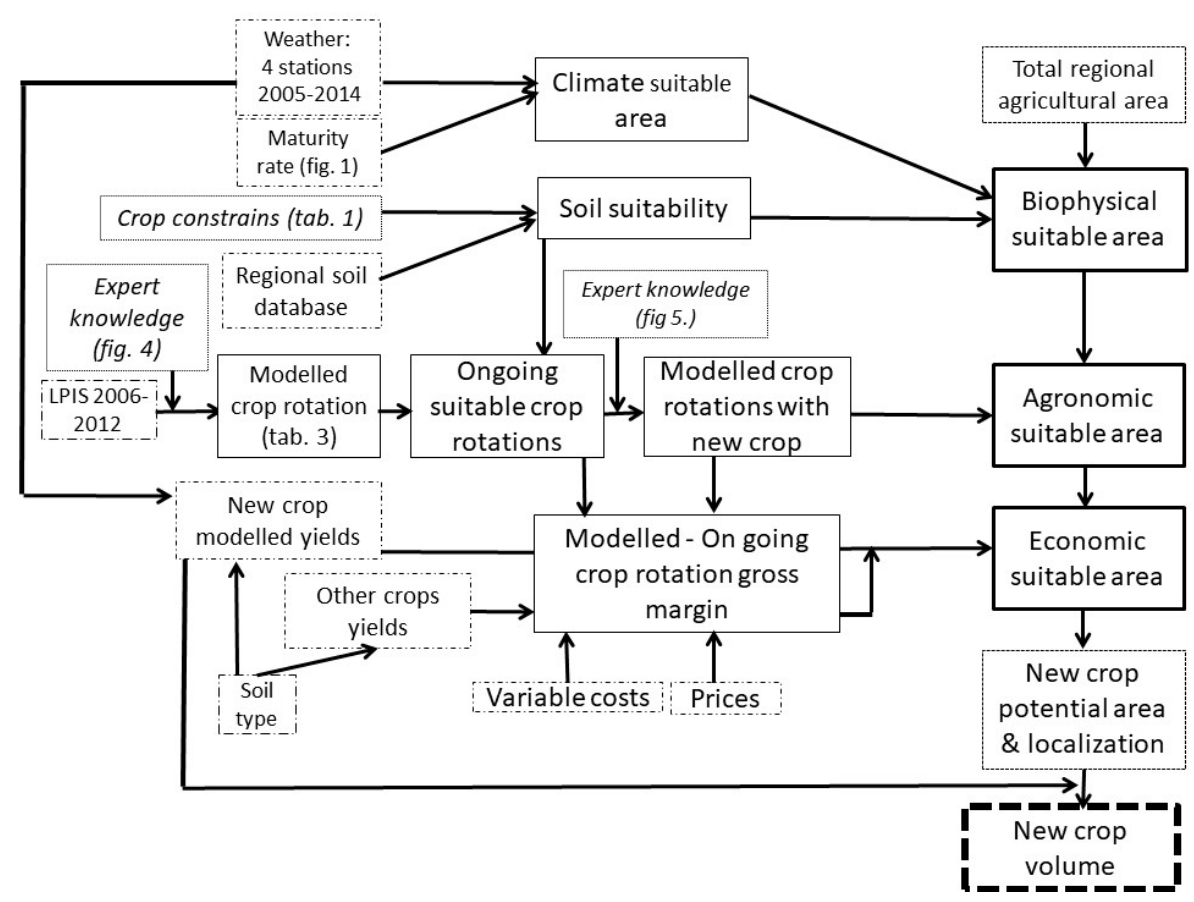

Figure 1. The overall method to assess the suitable areas (and the potential crop harvested) suitable for a new crop introduction into a region crop rotations. The method takes into account bio-physical, agronomic and economic suitability. LPIS indicates the Land Parcel Identification System described in [28]. 
The reference spatial unit for the method is the farmer's parcel. Land Parcel Identification System (LPIS) has been used as a database to map farmers' parcels and to model crop rotations. A crop rotation is a sequence of crops allocated by a farmer to a parcel and repeated over time [22]. In each spatial unit, several crop rotations can occur at the same time, while crop sequences are limited to the order of appearance of the crops during a fixed period of time [29,30]. The modelled crop rotations are attributed to each soil type in the reference spatial unit. The new crop yield is modelled in several soil types and weather conditions using a crop model. On the other hand, for the other crops, where agronomic references are already known, regional crop yields per soil type can be used. This means that yield variability is maximized but only for the new crop. Thus, in order to reduce this variability in the economic assessment, the average modelled yield of the new crop per soil type in the time span considered was used. In our method, the economic impact of the introduction of the new crop is estimated in the cropping system and not exclusively at the crop level, to take into account the previous-following crop when estimating the costs. The difference in gross margin between the modelled and the ongoing crop rotation is used as the indicator of the new crop suitability. In the following sections we describe the steps of the method applied to the introduction of soybean in the Oise region (France).

\subsection{Case Study}

The Oise region (NUTS 3 in the Eurostat classification) is located in northern France (Figure 2). The main town is Beauvais (55,000 inhabitants), which is $85 \mathrm{~km}$ north of Paris. The climate in Oise is Atlantic central according to the environmental stratification of Europe proposed by [31]. Over the last decade, the Beauvais station has recorded an annual average temperature of $10.7^{\circ} \mathrm{C}\left(\min 6.2^{\circ} \mathrm{C}\right.$, $\max 15.3^{\circ} \mathrm{C}$ ) and average rainfall of $617 \mathrm{~mm}$. Soils are mainly deep silty loams with a high potential for arable crops. According to the French official agricultural statistics the average yields (2010-2016) of major crops are soft wheat, $8 \mathrm{t} / \mathrm{ha}$; rape seed, $3.7 \mathrm{t} / \mathrm{ha}$; and sugar beet, $84 \mathrm{t} / \mathrm{ha}$. As reported by the regional Agricultural Chamber [32], 40\% of the Oise farms are cereal crops-oriented (mainly soft wheat, rape seed and barley), 25\% are industrial crops-oriented (mainly sugar beet, potato, green pea and green beans) and 20\% are livestock-oriented (mainly dairy and cattle breeding). Grain legume crops are therefore important in local cropping systems both as fertility-building crops on cereal- and industrial-oriented farms and as a source of proteins for animal feeding in livestock farms.

To reach the objective of the French National Ecophyto 2 plan to reduce pesticide use by $50 \%$ by 2025 [33], more agronomic leverage is required for weed and pest control, such as the diversification of crop rotations, for example an increase of legume crops. The yields of pea and faba bean, the two common grain legume crops of the area, are very irregular and ranged from 3.5 to $5.5 \mathrm{t} / \mathrm{ha}$ between 2006 and 2014 [34]. Since 2004, new MG000 soybean varieties more suitable to the conditions of latitude $48^{\circ}$ N/S have been developed [35], however, in northern France soybean is still not cultivated (Figure 2). In this region, the introduction of soybean in local cropping systems is hampered by a lack of agronomical data on the yield of new soybean varieties, the uncertainty regarding the impact of soybean on the gross margins of farms and the absence of structured food-supply chains. 


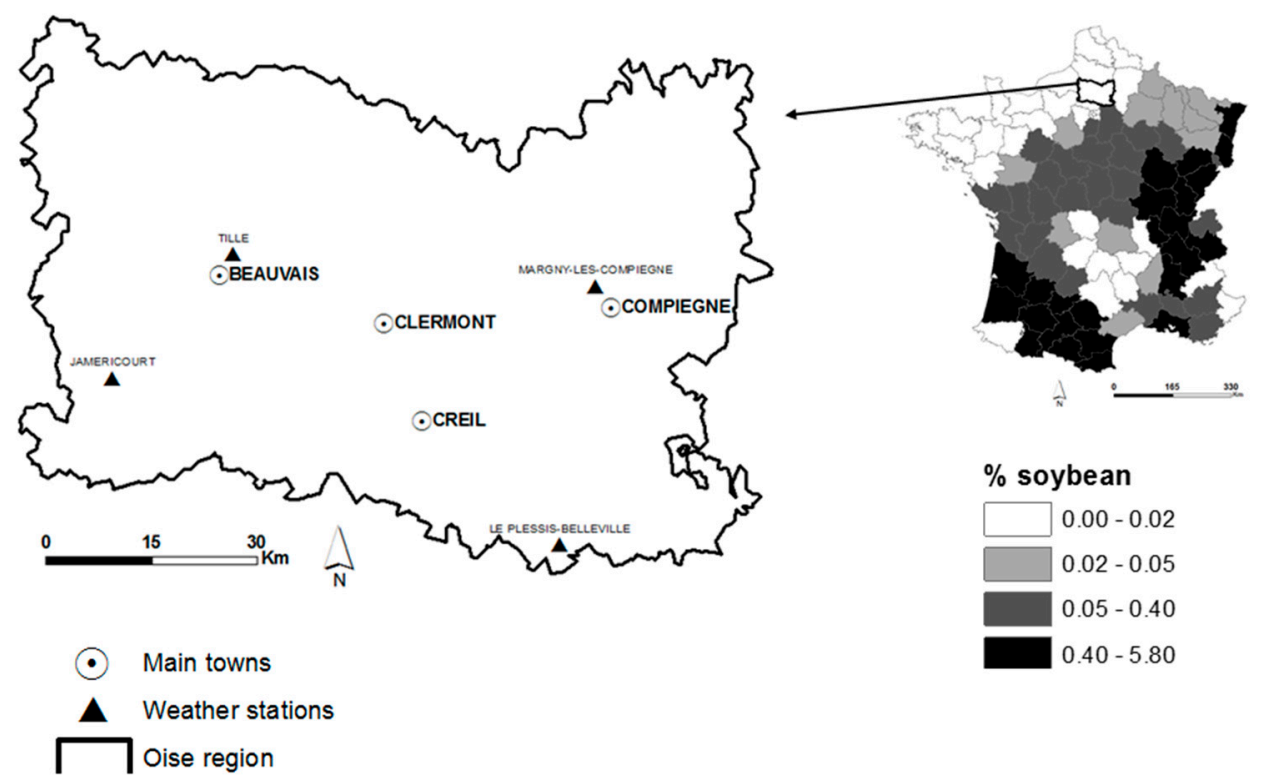

Figure 2. Location of the Oise region in northern France and the four meteorological stations used to determine the climatic suitability for soybean and for yield modelling. The map of France shows the soybean area in relation to the overall Usable Agricultural Area at the NUTS3 level [34].

\subsection{Biophysical Suitable Areas for Soybean in the Oise Region}

\subsubsection{Climate Suitability}

The area suitable for growing soybean was identified through two steps. The first was to use the climatic requirements of soybean to rule out unsuitable areas. The weather conditions of the region could be suitable for soybean as there is low risk of water stress during summer, which is cited as the main limit to rainfed soybean [36,37]. Aper et al. [38] reported that MG000 soybean varieties require 1435 Growing Degrees Days (GDDs) with a $6{ }^{\circ} \mathrm{C}$ base temperature. According to a study by a French technical institute [35], several frequencies of reaching soybean physiological maturity can be found in the Oise region, by considering a germination date of around the 24 May and a harvest date of around 1 October for the MG000 soybean varieties. The areas with a frequency higher than $80 \%$ were considered suitable for soybean, meaning that the crop was able to reach physiological maturity at least every 8 out of 10 years. In the second step, data from the last decade of four weather stations in the Oise region were used to identify four climatic areas for soybean based on the nearest municipalities around each weather station (Figure 2) which were used to spatialize the soybean yields obtained through the STICS simulations described in Section 2.6.

\subsubsection{Soil Suitability}

The regional soil database of the Oise region is available from the French information system on soils [39,40], at a 1:250,000 scale. Soil map units (SMUs) are delineated as soilscapes and each SMU generally includes more than one soil typological unit (STU). The STU dataset contains a description of the soil body characteristics. The SMU dataset contains the estimated percentage of each STU in each SMU area.

By using the regional soil database, the Soil Typological Units (STUs) of the area were distributed into three suitability classes for soybean production, according to the agronomic constraints for soybean. Three agronomic constraints were considered based on the literature and local expert knowledge (Table 1): iron deficiency chlorosis [41], harvest quality loss and hydric stress [42]. For summer crops under Oise climatic conditions these constraints were correlated to a high carbonate content $(>15 \%)$, a high stone/gravel abundance $(>15 \%)$ and a low soil-available water capacity $(<100 \mathrm{~mm})$. The SMUs of the area were then divided into five classes (Table 2), depending on the percentage of the 
three previously defined suitability classes in their area. The dominant STUs were identified in each suitability class in the SMU to provide a single soil attribute to yield assessment. In the Oise region, $57 \%$ of the SMU have a single suitability class and $13 \%$ a dominant suitability (more than $70 \%$ of the SMU area).

Table 1. Soil agronomic constraints for soybean according to [41,43]. STU indicates a Soil Typological Unit and AWC the Available Water Content.

\begin{tabular}{cc}
\hline STU Suitability Class & Agronomic Constraints \\
\hline Unsuitable & Carbonate $>15 \%$ or stone $/$ gravel $>15 \%$ or Soil-AWC $<100 \mathrm{~mm}$ \\
Suitable & Carbonate $<15 \%$ and stone $/$ gravel $<15 \%$ and $100<$ Soil-AWC $<170 \mathrm{~mm}$ \\
Highly suitable & Carbonate $<15 \%$ and stone/gravel $<15 \%$ and Soil-AWC $>170 \mathrm{~mm}$ \\
\hline
\end{tabular}

Table 2. Main soil suitability classes considered for soybean. SMU indicates the Soil Mapping Units.

\begin{tabular}{cc}
\hline SMU Suitability Class & Characteristics \\
\hline Homogeneous-unsuitable & $100 \%$ unsuitable \\
Homogeneous-suitable & $100 \%$ suitable \\
Homogeneous-highly suitable & $100 \%$ highly suitable \\
Heterogeneous & Partly unsuitable and partly suitable \\
Heterogeneous-suitable & Partly suitable and partly highly suitable \\
\hline
\end{tabular}

\subsection{Suitable Areas for Soybean from an Agronomic Point of View}

\subsubsection{Modelled Crop Rotation Based on Ongoing Crop Sequences}

The reference spatial unit in the French Land Parcel Identification System (LPIS) is the farmer block, considered as one or several parcels cultivated by a farmer [25]. The LPIS from 2006 to 2012 was used to determine the ongoing crop sequences in groups of farmers' blocks with the same proportion of crops, as preliminary information for identifying the crop rotations at the farmer block level. Only the crop sequences of the farmer blocks in the bio-physically suitable area for soybean were considered. The first step was to eliminate the non-agricultural land uses in this area (forest, roads, cities, etc.) by using the CORINE Land Cover [44], then the farmer blocks corresponding to seven years' LPIS data were mapped and overlaid with ArcMap 10.3 software $@$ (Esri Inc., Redlands, CA, USA). Farmer blocks were considered identical when their area difference was lower than $5 \%$ and had a shift in centroid of less than $12 \mathrm{~m}$, according to the method developed by [45]. All the farmer blocks with permanent crops (permanent pasture, orchards, vineyards, nuts, fruit trees, others) or fallow were eliminated because they were not suitable for soybean, as well those with at least one forage crop in order to avoid any reduction in forage availability on livestock farms. The farmer blocks with the code "seeds" or "green grain legumes" at least once among the seven years were eliminated because they represented a small area in the LPIS database (less than $0.1 \%$ of the agricultural surface) and are high added-value contract crops whose area has to be preserved. Wheat, barley and "other cereals" were considered together as cereals. The proportions of each crop in the seven years by farmer block were calculated and average crop distribution by farmer block identified. This crop distribution was coupled with our expert knowledge of regional crop rotations to establish the successions at the farmer block. For instance, in a farmer block presenting in 2006-2012 a succession R/C/C/R/C/C (R indicates rape seed and C cereals), the proportion of each crop was $29 \% \mathrm{R}$ and $71 \% \mathrm{C}$, which was modelled as $25 \% \mathrm{R}$ and $75 \% \mathrm{C}$ resulting in a modelled crop rotation in the field block of $\mathrm{R} / \mathrm{C} / \mathrm{C} / \mathrm{C}$. Crops with less than $5 \%$ in the distribution (equivalent to $1 / 3$ of the area in one of the seven years) were eliminated and the crop distribution was corrected. As the crop rotations are not always seven years long, the number of each crop occurrences within the seven years would not correspond to the real number of its occurrences in the rotation. For example, the rotation sugar beet/cereal/cereal/pea/cereal $(\mathrm{SB} / \mathrm{C} / \mathrm{C} / \mathrm{P} / \mathrm{C})$ may appear within the seven years as "SB/C/C/P/C/SB/C" or " $C / C / P / C / S B / C / C$ " or " $C / P / C / S B / C / C / P$ " or 
"P/C/SB/C/C/P/C", which do not present the same frequency of each crop (2/7 or $1 / 7$ for SB or $\mathrm{P}, 4 / 7$ or $5 / 7$ for $C$, according to the situation). To minimize this bias, the frequency of each crop in each farmer block was estimated as its mean frequency in all farmer blocks having the same combination of crops (farmer block group), considering that if all situations are represented homogenously in the farmers blocks group, the mean frequency of each crop will converge to its real frequency.

Ongoing crop rotations were modelled for each farmer block group following agronomic rules, where break crops are always followed by a cereal. If there were more cereals than break crops, the cereals were also distributed as a second cereal.

Both soil suitability class (Table 2) and crop rotation(s) in the farmers' blocks were considered as the agronomic criterion to identify the farmer blocks suitable for the introduction of soybean. Each SMU was characterized by its suitability classes (see previous paragraph), and some SMUs had a single class while others had more than one. By spatially joining the farmer blocks with the SMU, each of them characterized by a suitability class, it was possible to identify if a block was located within a homogeneous SMU (only one suitability class) or not. For farmer blocks located in heterogeneous $\mathrm{SMU}$, the presence of demanding crops (i.e., crops that needs more than $170 \mathrm{~mm}$ soil-available water capacity) in the ongoing crop rotation was considered as revealing suitable soils.

Farmer blocks with a single crop every year from 2006 to 2012 were then assumed to be homogeneous and suitable or not suitable for soybean according to the occurrence of at least one demanding crop during this 7 year period. Farmer blocks with two crops or more crops per year at least once between 2006 and 2012 were assumed to be heterogeneous and their suitable part was evaluated on the basis of the main surface of demanding crops from 2006 to 2012, as shown in Figure 3.

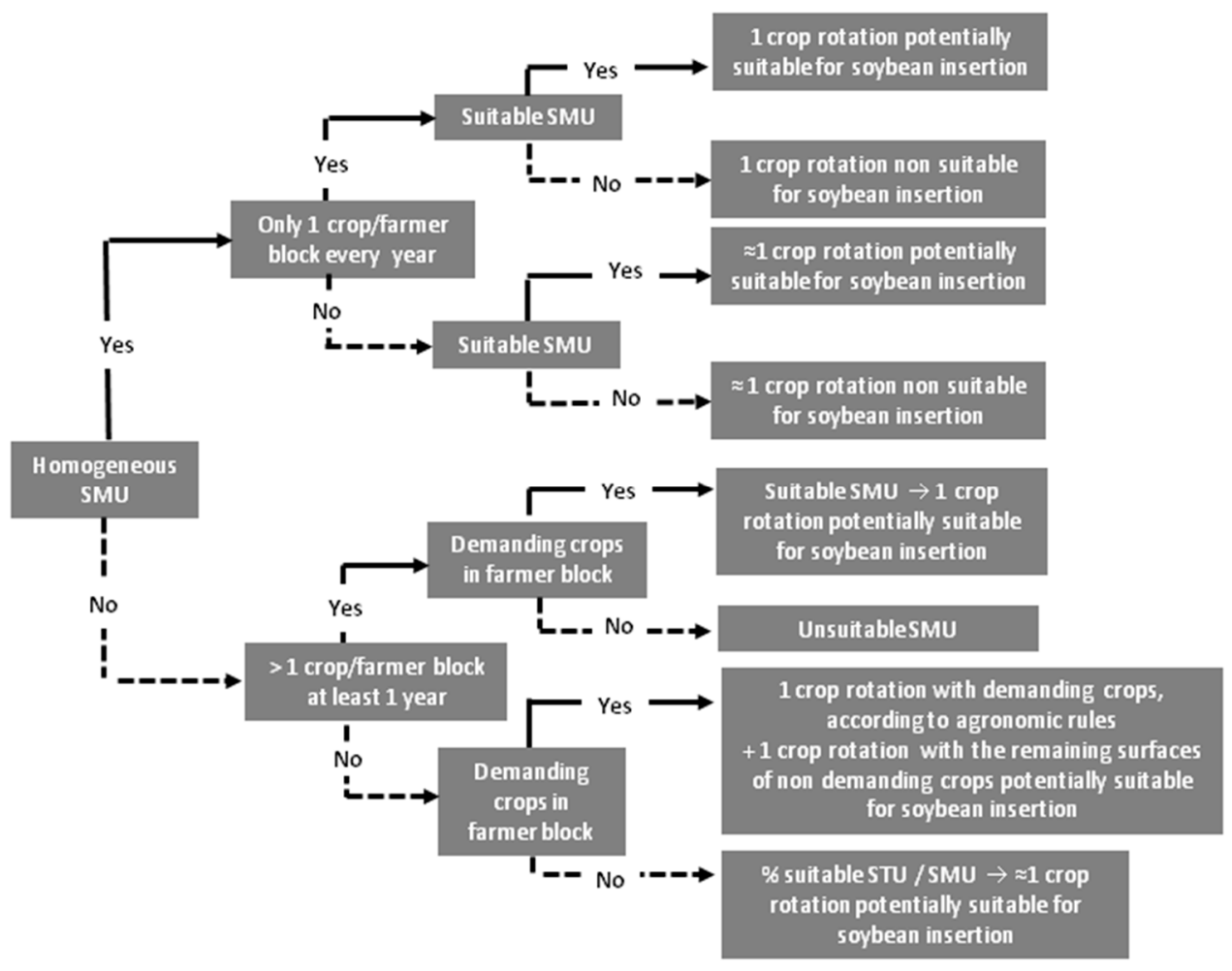

Figure 3. Decision rules to identify the suitable Soil Mapping Units (SMU) within farmer blocks for soybean introduction.

\subsubsection{Re-Designed Crop Rotations with Soybean}

On the farmer blocks where climate and soil were suitable for the soybean crop, each crop rotation modelled was evaluated to determine its potential to insert soybean (location and frequency) according to several agronomic decision rules (Figure 4). Crop sequence and frequency restriction 
were considered to both avoid phytosanitary problems and reduce the contract crop (crops where the harvest is already sold before sowing) area. Hence, soybean introduction should not decrease the contract crops area, yield or costs as they have an intensive management. The minimum sequential break of soybean was fixed to four years.

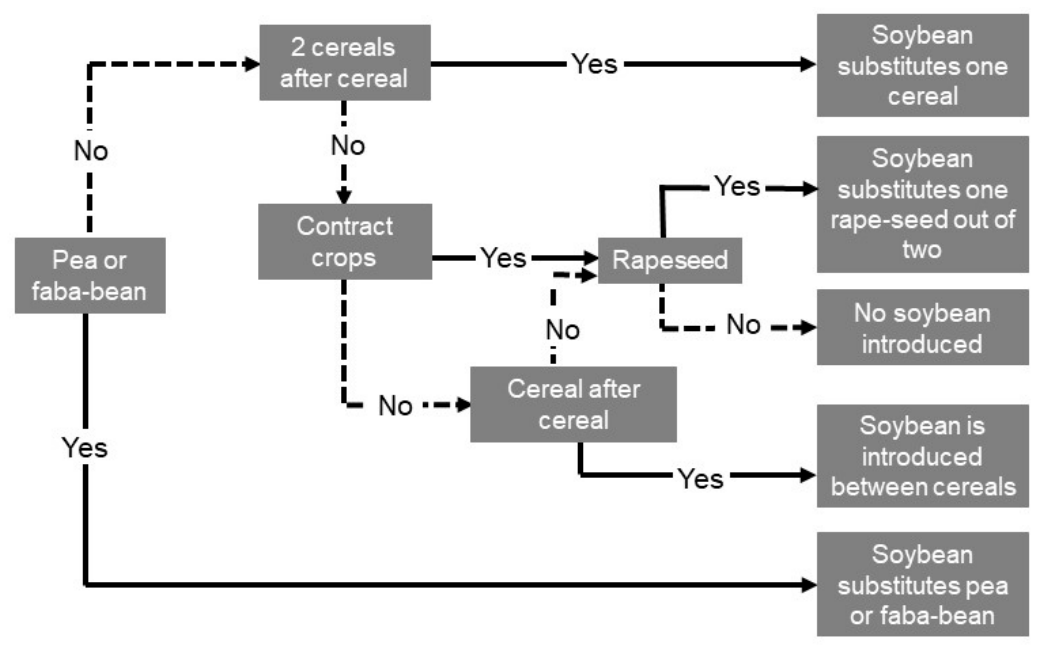

Figure 4. Decision rules to insert soybean in crop sequences based on the presence or absence in the 7 year crop rotation.

\subsection{Economic Suitable Areas for Soybean}

The difference between the gross margins of the modelled ongoing rotation and of the re-designed rotation including soybean was chosen as the economic indicator to determine the profitability of introducing soybean in a farmer block. A difference of $-50 €$ of this indicator was considered acceptable by farmers as providing agronomical advantage through soybean introduction. A gross margin difference below $-50 €$ was considered, therefore, as unsuitable for soybean introduction, a gross margin difference between $-50 €$ and $50 €$ as suitable and over $50 €$ very suitable. The gross margin was calculated by subtracting the variable costs from the total revenues per hectare. The revenues were calculated as:

$$
\text { Revenues }=\left(\sum_{\text {crop } 1}^{\text {crop } n}(\text { yield } f(\text { soil }) * \text { price })+\text { subsidies }\right)
$$

The crops' yields (including of soybean), the selling prices and variable costs were required to calculate the gross margin (Figure 1).

\subsection{Crops' Yields-Soybean}

The STICS model [46] was used to estimate the potential yield of soybean. STICS has already been validated for Northern French conditions for wheat and maize [47]. The model has been already parameterized on the soybean GM00 variety in Canada [48], although not yet for GM000. The model requires four main groups of data: climate, soil properties, plant and variety descriptors and crop management. By using the data of four weather stations in the Oise region over the last decade, as described in the climatic suitability paragraph, four climatic areas were identified for soybean around each weather station. The four meteorological stations (Figure 2) were located at Beauvais $\left(49^{\circ} 25^{\prime} \mathrm{N}, 2^{\circ} 05^{\prime} \mathrm{E}\right)$, Jaméricourt $\left(49^{\circ} 18^{\prime} \mathrm{N}, 1^{\circ} 52^{\prime} \mathrm{E}\right)$, Le Plessis-Belleville $\left(49^{\circ} 05^{\prime} \mathrm{N}, 2^{\circ} 45^{\prime} \mathrm{E}\right)$ and Margny-lès-Compiègne $\left(49^{\circ} 25^{\prime} \mathrm{N}, 2^{\circ} 49^{\prime} \mathrm{E}\right)$. The weather over the last ten years (from 2005 to 2014 ) was used to run STICS model simulations with daily temperatures (minimal and maximal), global radiation and precipitations, and evapotranspiration measured every ten days.

The most abundant soil types were considered-SiL-I, SiL-c, SaL-I, SaL-c CaL, HsiL-I, Lr, L-I-for the simulations. These soils types were attributed to the SMUs according to their physical characteristics 
and their AWC. Their physical characteristics were obtained from Ansel et al. [54]. A detailed description of each soil is given in Table A1. All crop management parameters were left by default except to confirm that there was no fertilization or irrigation during the crop and to define sowing conditions. The sowing date was fixed at the 106th Julian day and the density was 55 grains $\mathrm{m}^{-2}$ and had a sowing depth of $4 \mathrm{~cm}$ according to local advisors (personal communication). The plant selected was soybean and the variety was a MG00 variety. Once yields per soil type and climatic station were obtained, they were attributed to the different SMUs.

\subsection{Crops' Yields_Crops Other Than Soybean}

The yields of crops other than soybean were based on the regional references of the PERSYST tool [49] where initial soil types where transformed into seven simplified types to obtain the required references (Table 3). The effect of crop rotation on yield was considered according to [50,51]. So, the yield of the cereal after a cereal was reduced by $0.5 \mathrm{t} / \mathrm{ha}$, the yield of the cereal after a legume was increased $0.8 \mathrm{t} / \mathrm{ha}$ and the yield of rape seed after a legume was increased by $0.4 \mathrm{t} / \mathrm{ha}$.

Table 3. Reference yields ( $t /$ ha) as function of the soil types used to calculate gross margin. AWC: available water capacity [49].

\begin{tabular}{lccccccc}
\hline \multicolumn{1}{c}{ Crop } & $\begin{array}{c}\text { Light, } \\
\text { High } \\
\text { AWC }\end{array}$ & $\begin{array}{c}\text { Light } \\
\text { Medium/Low } \\
\text { AWC }\end{array}$ & $\begin{array}{c}\text { Chalky } \\
\text { Low AWC }\end{array}$ & $\begin{array}{c}\text { Clayey } \\
\text { High } \\
\text { AWC }\end{array}$ & $\begin{array}{c}\text { Clayey, } \\
\text { Medium } \\
\text { AWC }\end{array}$ & $\begin{array}{c}\text { Loamy, } \\
\text { High } \\
\text { AWC }\end{array}$ & $\begin{array}{c}\text { Loamy, } \\
\text { Medium } \\
\text { AWC }\end{array}$ \\
\hline $\begin{array}{l}\text { Winter soft } \\
\text { wheat }\end{array}$ & 8.4 & 7.2 & 8.3 & 7.6 & 8.2 & 9.7 & 9.2 \\
\hline Winter & & & & & & & \\
barley & 8.5 & 7.2 & 8.0 & 7.5 & 8.0 & 9.2 & 8.8 \\
\hline Summer & & & & & & & \\
barley & 6.5 & 5.4 & 5.7 & 5.1 & 6.5 & 7.3 & 6.5 \\
\hline Rape seed & 4.0 & 3.4 & 3.5 & 3.4 & 3.5 & 45 & 4.3 \\
Sugar beet & 70.0 & 70.0 & 80.0 & 95.0 & 95.0 & 105.0 & 105.0 \\
Grain corn & 8.3 & 8.5 & - & - & 8.5 & 10.3 & 9.2 \\
Legumes & 4.8 & 4.4 & 4.1 & - & 5.0 & 5.5 & 5.0 \\
Sunflower & 2.0 & 1.5 & 2.2 & 2.5 & 2.5 & 3.0 & 2.7 \\
Linseed & 2.6 & 2.6 & 2.1 & 2.2 & 2.5 & 2.8 & 2.5 \\
Flaxseed & 6.5 & 5.1 & 4.8 & - & - & 6.8 & 6.1 \\
\hline
\end{tabular}

\subsection{Crop Selling Prices}

Two simulations were made with two crop selling prices (Table 4) based on the highest and the lowest average prices between 2010 and 2014 for each crop from the regional statistics [52]. For grain legume crops the gross margin difference corresponded to the difference in income (yield x price) of grain legumes and soybean, as variable costs were considered as being similar.

The variability of the farm type and the policy support meant that only a 150 euros/ha subsidy for grain legumes was considered. 
Table 4. Total variable costs per crop (excluding nitrogen fertilizer costs) according to local references [52] and selling prices according to the minimal and maximal prices retrieved between 2010 and 2014.

\begin{tabular}{cccc}
\hline Crop & Variable Costs (€/ha) & High Selling Price $(\mathbf{\epsilon} / \mathbf{t})$ & Low Selling Price $(\mathbf{\epsilon} / \mathbf{t})$ \\
\hline Wheat & 382 & 190 & 150 \\
Barley & 288 & 190 & 140 \\
Legume & 418 & 220 & 170 \\
Rape seed & 329 & 440 & 300 \\
\hline Industrial vegetables & & Fixed (contract crops) & 0 \\
\hline Set-aside & 0 & 0 & 350 \\
Soybean & 522 & 450 & 140 \\
Oat & 240 & 180 & 180 \\
Sugar Beet & Fixed (contract crop) & 140 \\
Flaxseed & 270 & 380 \\
Corn & 408 & 190 & 325 \\
Linseed & 452 & 490 & \\
Sunflower & 300 & 460 & \\
\hline
\end{tabular}

\subsection{Variable Costs}

The variable costs were calculated according to local references [52], and consisted of phosphorus and potassium fertilizers, phytochemicals, seeds, harvest and post-harvest costs. The total variable costs (excluding nitrogen fertilizer costs) per crop are provided in Table 4. For herbicide costs in addition to the local references, an increase in 20 euros/ha if a second cereal follows another cereal was considered and a decrease by the same when a cereal follows a summer non-cereal crop. A supplementary phytochemical seed treatment of 20 euros/ha is also expected if a cereal follows another cereal (personal communication from local advisors). A cover crop previous to summer crops is also required, which has a seed cost of 40 euros/ha. Post-harvest costs of drying for soybean and sunflower were estimated according to local references as 25 euros/t (18\% and $15 \%$ harvest humidity respectively) whereas for corn they were estimated at 35 euros/t (35\% harvest humidity).

The need of nitrogen fertilizers (Nf) was estimated for each crop to calculate the total nitrogen fertilizer costs. According to [53] this cost is calculated as the difference between the nitrogen soil supplies and the nitrogen crop requirements. Soil types were considered as tilled, as tillage is the dominant practice in the region. Soil types defined by [54] were considered to ascertain the soil depth, soil mineralization and the non-extractable nitrogen.

\subsection{Potential for Soybean Introduction in the Oise Region}

The potential for soybean introduction in the Oise region was assessed as the calculated volume and the spatial distribution of soybean production each year in the region. To assess this volume, the soybean yield, calculated for each soil type and climatic zone, was multiplied by the area devoted to soybean in the economically suitable or very suitable farmers' blocks each year, i.e., those with a delta gross margin after soybean introduction of over -50 euros/ha.

\section{Results}

\subsection{Suitable Climatic Area for Soybean Introduction}

The spatial distribution of the agricultural farmers' blocks suitable for soybean introduction in Oise crop rotations under climatic conditions is illustrated in Figure $5 \mathrm{a}$ and was equal to 82,238 ha in total, which was $14 \%$ of the Oise area and $22 \%$ of the Oise UAA in 2014. 
(a)

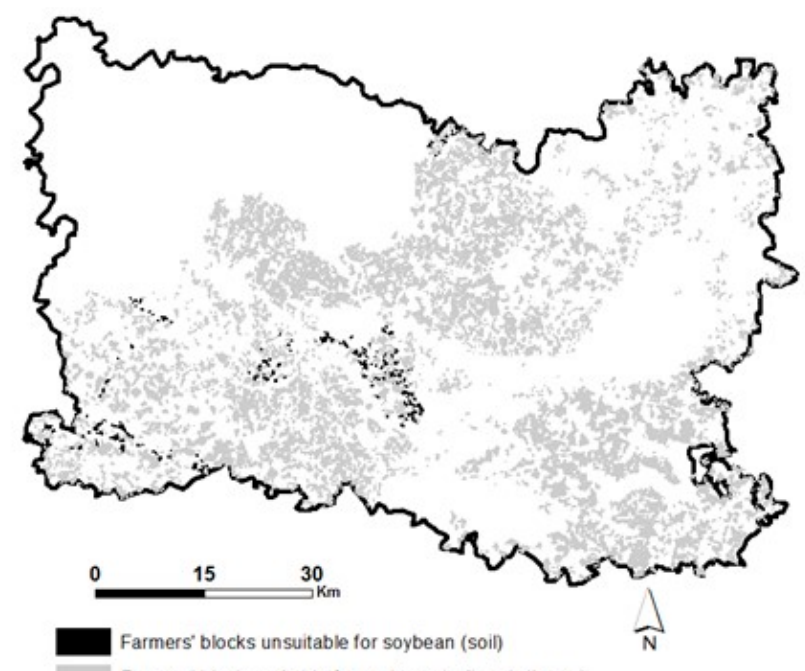

(b)

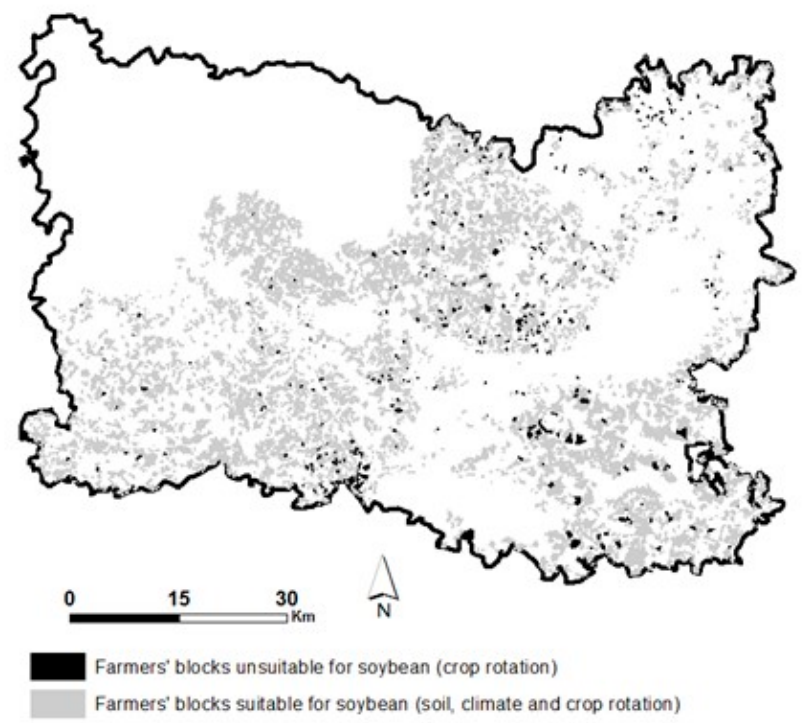

Figure 5. Spatial distribution of suitable areas for soybean cultivation in the Oise region according to bio-physical (a) and agronomic suitability (b). White areas are either non-agricultural areas or climatically unsuitable for soybean production.

The unsuitable areas were concentrated in the North-Western part of the region and were mainly due to climate limitations. Four different areas contributed between $17 \%$ and $36 \%$ to the favourable climatic area. Within these areas, the average farmer block area are quite different, particularly between the northern (Tillé and Margny-les-Compiègne) and southern (Jaméricourt, Le Plessis-Belleville) stations (Table 5).

Table 5. LPIS farmer block number and areas according to different weather stations in the soybean climatically suitable area of the Oise region.

\begin{tabular}{cccc}
\hline Weather Stations & Number of Farmer Blocks & $\begin{array}{c}\text { Total Farmer Block Area } \\
\text { (ha) }\end{array}$ & $\begin{array}{c}\text { \% of the Suitable Climatic } \\
\text { Agricultural Area }\end{array}$ \\
\hline Jaméricourt & 1614 & 13,898 & $17 \%$ \\
\hline Le Plessis-Belleville & 1575 & 18,868 & $23 \%$ \\
\hline Margny-lès-Compiègne & 5346 & 29,869 & $36 \%$ \\
\hline Tillé & 3786 & 19,748 & $24 \%$ \\
\hline
\end{tabular}




\subsection{Soil Suitable Area for Soybean}

Within the suitable climatic area, different soil types exist (Table 6). Table 6 shows that the most fertile soil (Loamy with high AWC) covers the highest part of the suitable climatic area. Chalky soil with low AWC is the only unsuitable soil for soybean, representing 1351 ha, and thus $1.6 \%$ of the climatically suitable area (Figure $5 b$ ).

Table 6. LPIS parcel number and areas according to different soil types in the soybean suitable climatic area of the Oise region. * indicates the soil type unsuitable for soybean, AWC the Available Water Content.

\begin{tabular}{cccc}
\hline Soil Type & $\begin{array}{c}\text { Number of Farmer } \\
\text { Blocks }\end{array}$ & $\begin{array}{c}\text { Total Farmer Blocks' } \\
\text { Area (ha) }\end{array}$ & $\begin{array}{c}\text { \% on the Climatically } \\
\text { Suitable Area }\end{array}$ \\
\hline Chalky, high AWC & 347 & 2139 & $2.6 \%$ \\
Chalky, low AWC & 545 & 3054 & $3.7 \%$ \\
Clayey, high AWC & 1790 & 7903 & $9.6 \%$ \\
\hline Clayey, medium/low AWC & 221 & 1416 & $1.7 \%$ \\
\hline Light, high AWC & 14 & 48 & $<0.01 \%$ \\
\hline Light, medium/low AWC & 1446 & 8902 & $10.8 \%$ \\
\hline Loamy, high AWC & 5370 & 42,624 & $51.7 \%$ \\
\hline Loamy, medium/low AWC & 2606 & 16,370 & $19.8 \%$ \\
\hline
\end{tabular}

\subsection{Suitable Areas for Soybean from an Agronomic Point of View}

Figure 5a shows the location of the farmers' blocks where an introduction of soybean is possible, according to the agronomic rules described. Only $4 \%$ of the farmers' blocks area (3304 ha), in both suitable climatic area and soil types, was unsuitable for soybean (Table 7). Long crop rotations including several contract crops and at least one year of rape seed account for this unsuitability on farmers' blocks located on very good soil types. The grain legume rule contributes to most of the agronomic suitable area, followed by the two cereals rule (Table 7).

Table 7. LPIS farmer blocks and areas according to different agronomic rules according to Figure 4 and soil types in the soybean climatic suitable areas of the Oise region. AWC indicates Available Water Capacity.

\begin{tabular}{|c|c|c|c|c|c|c|c|c|c|}
\hline \multirow{3}{*}{$\begin{array}{l}\text { Agronomic Introduction } \\
\text { Rule }\end{array}$} & \multirow{3}{*}{$\begin{array}{c}\text { Number } \\
\text { of } \\
\text { Farmers' } \\
\text { Blocks }\end{array}$} & \multirow{3}{*}{$\begin{array}{c}\text { Total } \\
\text { Blocks } \\
\text { Area } \\
\text { (ha) }\end{array}$} & \multicolumn{7}{|c|}{ Rate for Different Soil Type Area (\%) } \\
\hline & & & \multicolumn{2}{|c|}{ Light } & \multirow{2}{*}{$\begin{array}{c}\text { Chalky } \\
\text { High } \\
\text { AWC }\end{array}$} & \multicolumn{2}{|c|}{ Clayey } & \multicolumn{2}{|c|}{ Loamy } \\
\hline & & & $\begin{array}{l}\text { High } \\
\text { AWC }\end{array}$ & $\begin{array}{l}\text { Medium/Low } \\
\text { AWC }\end{array}$ & & $\begin{array}{l}\text { High } \\
\text { AWC }\end{array}$ & $\begin{array}{l}\text { Medium } \\
\text { AWC }\end{array}$ & $\begin{array}{l}\text { High } \\
\text { AWC }\end{array}$ & $\begin{array}{l}\text { Medium } \\
\text { AWC }\end{array}$ \\
\hline One cereal over 2 cereals & 3171 & 22,597 & 0 & 13.1 & 2.1 & 0 & 2.4 & 57.5 & 24.7 \\
\hline One cereal over 3 cereals & 1290 & 5198 & 0.2 & 18.1 & 3.5 & 0 & 1.9 & 47.8 & 28.3 \\
\hline Grain legumes & 6482 & 47,578 & 0 & 10.1 & 3.1 & 11.3 & 15.8 & 51.4 & 19.0 \\
\hline No soybean & 440 & 3304 & 0.1 & 5.4 & 0.4 & 6.8 & 0.6 & 77.8 & 8.0 \\
\hline
\end{tabular}

\subsection{Soybean Yield Simulation}

The mean simulated yields ( $0 \%$ humidity) from 2005 to 2014 in each soil and weather condition type are illustrated in Figure 6.

Soils with the highest mean yield were Deep Loam (SiL-I, equivalent to Loamy high AWC) with $2.62 \mathrm{t} / \mathrm{ha}$, and Deep Loam/silt loam (L-r, $2.19 \mathrm{t} / \mathrm{ha}$, Loamy medium AWC). Soils with the lowest mean yield were Shallow Calcareous (CaL, $1.06 \mathrm{t} / \mathrm{ha}$, Chalky low AWC) and Moderately Deep Sandy Loam (SaL-c, $1.19 \mathrm{t} / \mathrm{ha}$, Light high AWC). For the four weather stations, the soil with the highest maximal and the soil with minimal yield were the same: SiL-I had a mean maxima and mean minima of 3.29 and 
$1.28 \mathrm{t} /$ ha respectively and L-r 3.14 and $0.91 \mathrm{t} / \mathrm{ha}$. Within locations, Le Plessis Belleville had the highest yield (3.73 t/ha) on SiL-I soil in 2012, and Jaméricourt had the lowest yield on hSiL-I soil (1.52t/ha) in 2008. SiL-I also had the lowest yield variability within years, followed by L-r soil type.
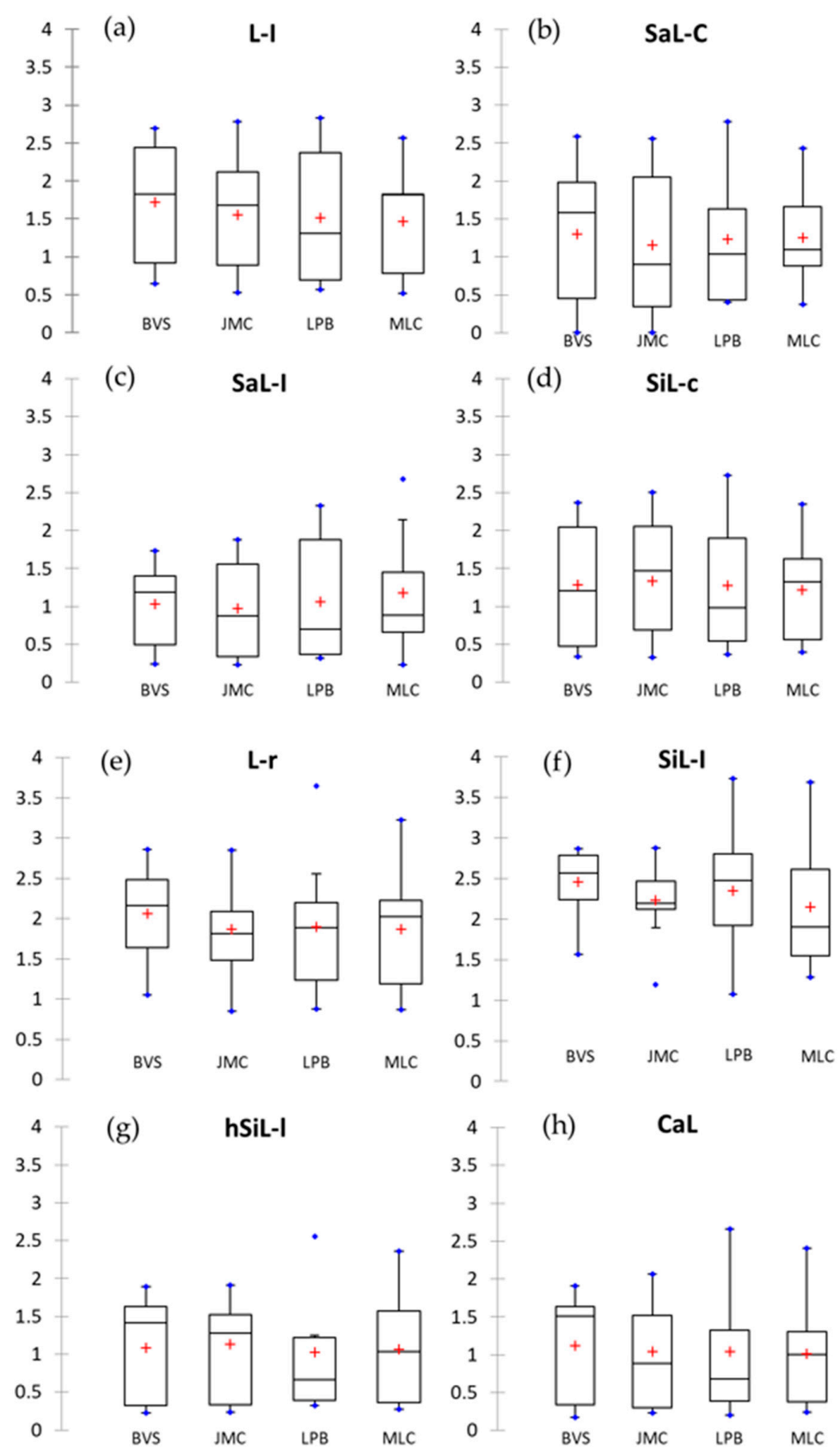

Figure 6. Box plot of the simulated soybean yields ( $\mathrm{t} \% \%$ humidity/ha) with STICS for each soil type (a) L-I, deep loam; (b) SaL-c, Moderately deep sandy loam; (c) SaL-I, Moderately deep sandy loam; (d) SiL-c, Moderately deep silty loam; (e) L-r, Deep loam/silt loam; (f) SiL-I, Deep loam; (g) hSiL-I, Moderately deep silt loam hydromorphic; (h) CaL, Shallow calcareous for ten considered years (2005-2014) in the four stations considered BVS: Beauvais, JMC: Jaméricourt, MLC, Margny-lès-Compiègne, LPB, Le Plessis Bellevile. 


\subsection{Economic Suitability for Soybean}

The farmers' blocks were considered as suitable if they had a difference in gross margin between the re-designed modelled crop rotation with soybean and the ongoing crop rotation of below -50 euros/ha and were thus in the suitable or very suitable cases. Figure 7 highlights the distribution of the suitable and unsuitable farmers' blocks under a high Figure $7 \mathrm{a}$ and a low Figure $7 \mathrm{~b}$ crop price scenario. In the blocks considered as very suitable (difference of gross margin after soybean introduction higher than +50 euros), the soybean introduction (area and localization) did not appear to change depending on the crop prices. A part of the blocks defined as suitable shifts to unsuitable when the crop price increases (Table 8). This suggests that under high price conditions, soybean is less competitive than other crops. For example, Table 8 shows that $81 \%$ of the farmers' blocks with a two cereal introduction rule are very suitable to soybean introduction under low price conditions, whereas only $10 \%$ of the same blocks area is very suitable under high price conditions.

\section{(a)}

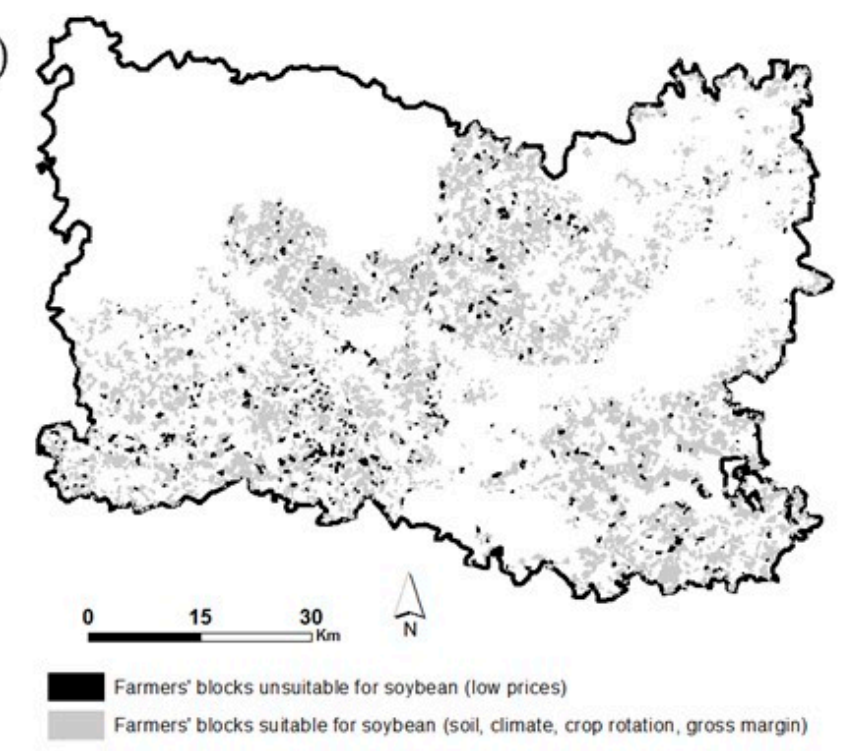

(b)

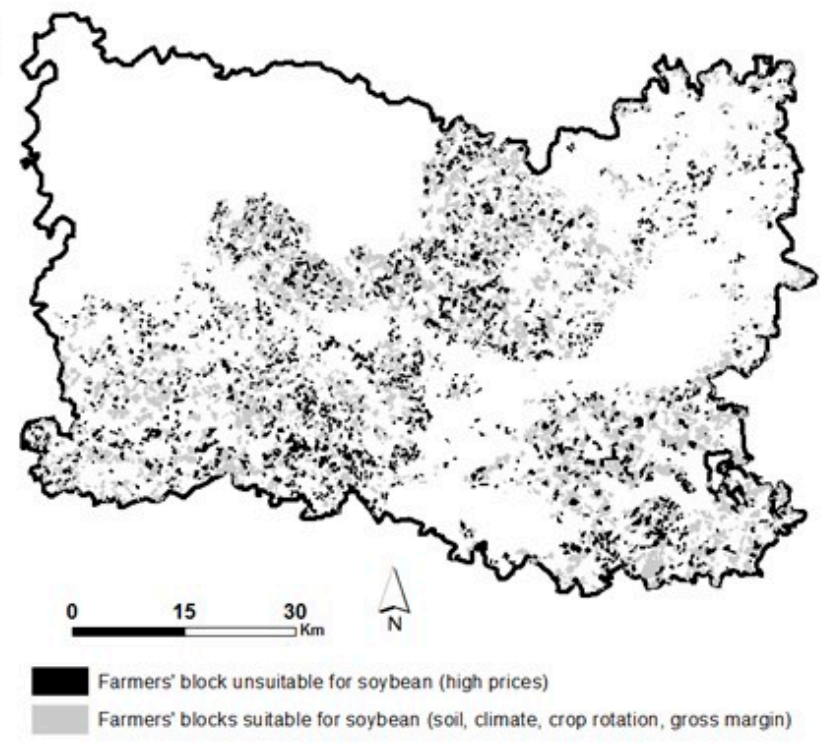

Figure 7. Spatial distribution of suitable areas for soybean introduction according to gross margin difference after soybean introduction in suitable crop rotations under low crops' selling prices (a) and high crops' selling prices (b) defined in Table 4. White areas are either non-agricultural areas either unsuitable area for soybean for climate, soil or crop rotations. 
Table 8. Variability of the gross margin after the introduction of soybean for different crop price conditions (Table 3), farmers' block types (Figure 3) and soybean introduction rules (Figure 4). Unsuitable conditions exist when the gross margin difference after soybean introduction is below $-50 €$, suitable conditions exist when the difference is between $-50 €$ and $+50 €$, and very suitable when the difference is over $+50 €$.

\begin{tabular}{|c|c|c|c|c|c|c|c|}
\hline & \multirow[b]{2}{*}{$\begin{array}{l}\text { Variability of the Gross } \\
\text { Margin after Soybean } \\
\text { Introduction }\end{array}$} & \multirow[b]{2}{*}{$\begin{array}{l}\text { Farmers' } \\
\text { Blocks }\end{array}$} & \multirow[b]{2}{*}{$\begin{array}{l}\text { Total Area } \\
\text { (ha) }\end{array}$} & \multicolumn{4}{|c|}{$\begin{array}{l}\text { Area Rate for Different Soybean Introduction } \\
\text { Rules (\%) }\end{array}$} \\
\hline & & & & $\begin{array}{c}\text { One } \\
\text { Cereal } \\
\text { over } 2 \\
\text { Cereals }\end{array}$ & $\begin{array}{c}\text { One } \\
\text { Cereal } \\
\text { over } 3 \\
\text { Cereals }\end{array}$ & $\begin{array}{l}\text { Between } \\
\text { two Rape } \\
\text { Seeds }\end{array}$ & $\begin{array}{c}\text { Grain } \\
\text { Legumes }\end{array}$ \\
\hline \multirow{3}{*}{ Low price } & Very suitable & 5739 & 46,417 & $81 \%$ & $2 \%$ & $0 \%$ & $17 \%$ \\
\hline & Suitable & 3902 & 19,691 & $72 \%$ & $20 \%$ & $0 \%$ & $7 \%$ \\
\hline & Unsuitable & 528 & 5354 & $89 \%$ & $10 \%$ & $1 \%$ & $0 \%$ \\
\hline \multirow{3}{*}{ High price } & Very suitable & 5721 & 46,079 & $10 \%$ & $2 \%$ & $0 \%$ & $88 \%$ \\
\hline & Suitable & 1748 & 8711 & $40 \%$ & $43 \%$ & $0 \%$ & $17 \%$ \\
\hline & Unsuitable & 2700 & 16,672 & $94 \%$ & $5 \%$ & $1 \%$ & $0 \%$ \\
\hline
\end{tabular}

\subsection{Potential for Soybean Production in the Oise Region}

Within the areas suitable for soybean introduction from climatic, soil type, agronomic and economic points of view, the total soybean potentially produced is of 11,108 tons per year under a scenario of low crop selling prices, and of 8801 tons per year under a scenario of high crop selling prices with mean yields per soil type. The former is produced in a total area of 6187 hectares per year $(7.5 \%$ of the climatic suitable area for soybean), while the latter in an area of 4878 hectares per year (6\% of the climatic suitable area for soybean). These areas are derived from the suitable overall areas defined in Table 6 by taking into account the yearly surface of soybean in the re-designed crop rotations.

\section{Discussion}

In a general context requiring crop diversification, the question of which new crop to introduce in arable cropping systems is a major issue for farmers and local agricultural actors. One of major barriers to diversification is the lack of local agronomic references on innovative crops. The novelty of our research was the development of a land suitability method for use when no agronomic local references on the crop of interest exist. Our method is innovative since it adds spatially-explicit agronomic knowledge to common land suitability methods by addressing the suitability of the ongoing crop rotations for the introduction of a new crop and its subsequent effect on the gross margin. We validated our method by testing the case of the suitability of introducing MG000 soybean into the crop rotations of the Oise region (northern France). As yet soybean has not been cultivated in northern France, while MG000 soybean varieties are currently being cultivated or experimented at similar latitudes in the US, Canada or in Belgium $[38,48,55]$. The discussion of the method is divided into three parts: the sources of uncertainty in relation to the land suitability results (4.1), the barriers to the adoption of a new crop (4.2) and the general applicability of the method (4.3). 
4.1. Uncertainty Regarding the Land Suitability Results is Highly Dependent on Assumptions on Crop Allocation, Farmers Practices and Data Availability

Working at the regional level requires a combination of heterogeneous data with different spatial, temporal and thematic (e.g., the crop classes within the LPIS database) resolutions [56]. Methods such as modelling, and spatial and economic analyses must also be combined to answer the research questions. When dealing with the land suitability for a crop without any agronomic local reference, the quality of the data and the main hypothesis are of primary importance in relation to the uncertainty of the final results. In the case study developed, as soybean is not yet cultivated in the region, the analysis performed was based on different hypotheses regarding climate, soil quality, introduction within the ongoing crop sequences, potential yields of the main crops and rotational gross margin. The obtained results are influenced by these hypotheses, but in general the present method underestimated the amount and the surface of the new crop that can be produced in the region. Among the different potential sources of uncertainty, the most innovative point of the current method is discussed, this is the introduction of a new crop within the ongoing crop sequences.

In this step of the method, farmers' blocks with more than one crop per year at least once during the seven years modelled long rotations. However, the real rotations could be shorter but repeated on the other fields that constitute the farmer block. Comparison of soybean introduction in modelled crop rotations under the hypothesis of one long or two short rotations shows significant differences, as highlighted in Table 9. As crop rotations leading to an underestimation of the soybean area are the most frequent, and the return period is shorter, the model underestimates the suitable area for soybean. The use of innovative tools for crop rotation generation such as the RPG Explorer tool [25,27] or LandSCFACTS [57] may improve the reliability of the crop rotation generation phase and support the adaptation of agronomical rules to regional crop rotations.

Table 9. Comparison of the impact of the rotation length on the soybean return period and on the estimation of the area allocated according to different crop sequences. C indicates cereals, $\mathrm{R}$ rape seed, $\mathrm{M}$ corn, OS oil seeds except rape seed, Pt potato and BS sugar beet. * soybean cannot be introduced in a rotation with maize.

\begin{tabular}{|c|c|c|c|c|c|}
\hline $\begin{array}{c}\text { Crops' Proportion } \\
\text { in the Crop } \\
\text { Sequence }\end{array}$ & $\begin{array}{l}\text { Hypothesis on } \\
\text { the Crop } \\
\text { Rotation }\end{array}$ & $\begin{array}{l}\text { Ongoing Crop } \\
\text { Rotation }\end{array}$ & $\begin{array}{l}\text { Applied } \\
\text { Agronomic } \\
\text { Rule }\end{array}$ & $\begin{array}{c}\text { Soybean } \\
\text { Return Period }\end{array}$ & $\begin{array}{c}\text { Effect of Short } \\
\text { Rotation } \\
\text { Hypothesis on } \\
\text { Soybean Area }\end{array}$ \\
\hline \multirow{2}{*}{$\begin{array}{c}\text { C: } 50 \% \\
\text { R: } 17 \% \\
\text { M: } 17 \% \\
\text { Set aside: } 16 \%\end{array}$} & Long: 5 years & $\mathrm{RCMCC}$ & $\begin{array}{c}\text { Soybean } \\
\text { substitutes one } \\
\text { R out of two }\end{array}$ & 10 years & \multirow[b]{2}{*}{$-25 \%$} \\
\hline & $\begin{array}{l}\text { Short: } 2 \\
\text { rotations of } 2 \\
\text { and } 3 \text { years }\end{array}$ & $\begin{array}{c}\frac{1}{2} \mathrm{RC} \\
\frac{1}{2} \mathrm{MCC}\end{array}$ & $\begin{array}{c}\text { Soybean } \\
\text { substitutes one } \\
\text { R out of two }\end{array}$ & $\begin{array}{c}4 \text { years on half } \\
\text { area * }\end{array}$ & \\
\hline \multirow{2}{*}{$\begin{array}{l}\text { C: } 60 \% \\
\text { R: } 20 \% \\
\text { M: } 10 \% \\
\text { OS: } 10 \%\end{array}$} & Long: 10 years & $\begin{array}{c}\text { MCOSCCRC } \\
\text { RCC }\end{array}$ & $\begin{array}{c}\text { Soybean } \\
\text { substitutes one } \\
\text { R out of two }\end{array}$ & 10 years & \multirow[b]{2}{*}{$+25 \%$} \\
\hline & $\begin{array}{c}\text { Short: } 2 \\
\text { rotations of } 5 \\
\text { years }\end{array}$ & $\begin{array}{c}\frac{1}{2} \mathrm{R} \mathrm{C} \mathrm{R} \mathrm{C} \mathrm{C} \\
\frac{1}{2} \mathrm{OSCCMC}\end{array}$ & $\begin{array}{c}\text { Soybean is } \\
\text { inserted } \\
\text { between two C }\end{array}$ & $\begin{array}{c}6 \text { years on half } \\
\text { area }\end{array}$ & \\
\hline \multirow{2}{*}{$\begin{array}{c}\text { C: } 50 \% \\
\text { R: } 6 \% \\
\text { SB: } 17 \% \\
\text { Pt: } 7 \% \\
\text { M: } 10 \% \\
\text { Set aside: } 8 \%\end{array}$} & Long: 12 years & $\begin{array}{c}\text { M C Pt C SB C SB } \\
\text { C R C SB C }\end{array}$ & $\begin{array}{c}\text { Soybean } \\
\text { substitutes one } \\
\text { R out of two }\end{array}$ & 24 years & \multirow{2}{*}{ No change } \\
\hline & $\begin{array}{c}\text { Short: } 2 \\
\text { rotations of } 6 \\
\text { years }\end{array}$ & $\begin{array}{l}\frac{1}{2} \text { Pt C SB C SB C } \\
\frac{1}{2} \text { R C M C SB C }\end{array}$ & $\begin{array}{c}\text { Soybean } \\
\text { substitutes one } \\
\text { R out of two }\end{array}$ & 24 years & \\
\hline
\end{tabular}




\subsection{Barriers to the Introduction of New Crops}

Although an area may have been identified as suitable for a new crop, there are several barriers that can reduce its adoption by farmers. The authors of $[7,58]$ argued that these barriers apply to different levels in the food supply chain. At the farm level, the adoption of a new crop is often hindered by diseases or disease risks that are extremely severe when production reaches a certain threshold and there are limiting climatic conditions. Often, in the case of a new crop, the risk of disease is low. This is for example the case of soybean in France due to the low intensity of soybean-based systems, which has also been reported in other European countries [59].

Other barriers include the presence of substitution crops (e.g., pea and faba bean for soybean), the impact of residual herbicide action, necessary modifications to machinery, lack of knowledge of inoculation techniques, and the lack of adapted genetic material. Other barriers depend on the risk aversion of farmers. One example of a barrier to the introduction of a new crop could be a lack of policy support to compensate the risk taken by the farmers. For example, until 2015, soybean was not considered as a grain legume in France but an oilseed crop, so it was not eligible for EU subsidies for grain legumes.

The lack of advice on new crops may also be a barrier, particularly when there is lack of references on the crop. This was underlined by the research of [45] who found that in a sample of farms in Luxembourg there was a lack of knowledge about grain legume cultivation. Finally, there are several important lock-in at the agrifood level, such as the historical preference for cereals and imported proteins or the specific French technological lock-in, as indicated by [60].

\subsection{General Interest of the Method}

In the general diversification trend to a more sustainable crop production, quantifying and localizing the amount and area of a new crop is essential information for agro-food companies and cooperatives in order to help them deciding whether, where and how to invest in a new crop. Our method provides such information. By furnishing spatially-explicit information on the crop yield and the possible introduction into ongoing crop rotation, the method could also be used for a preliminary screening of field trial locations for the new crop. In addition to the classical bio-physical screening our method also supplies information on the areas where the agronomic potential is higher and where farmers might be more interested for the new crop. The results provided by our method can support participatory workshops on cropping system design with farmers and advisors [60].

In addition to informing the food supply chain, which was the original goal of this research, our results support agricultural advisors in considering diversification alternatives for the arable cropping systems in intensive agricultural regions. By testing the method, we believe we have demonstrated that soybean, as a spring crop, could be a source of diversification in cereal-based rotations in Northern France, which are currently characterized by winter and monocotyledonous crops, thus reducing the risk of weed resistances both by reducing the number of weeds and by changing the herbicides' active constituents [61]. Our results also supported the establishment of soybean field trials, which will allow to improve the reliability of the ex-ante assessment we presented in this paper. First year results and parametrization of DSSAT model for early maturity varieties were presented by [62].

The main information needed to adopt our method consists of regional databases and expert knowledge. The regional databases needed are soil map information, climate information and a Land Parcel Identification System to identify and localize ongoing crop rotations. These databases are all available at the EU level and could be easily available in other countries in relation to soil and climate. The spatial resolution depends on the data source, which could be local or global. For soil, some information is also provided by the FAO Soils portal and by global soil mapping programs [63]. The spatial explicit information on the succession of annual crops can also be derived by remote sensing data (e.g., [64]) in non EU countries where a LPIS has not been implemented, although the advantage of the EU LPIS is that the information is directly supplied by farmers and refers to the surface area they manage [28]. 
Expert knowledge in our method is needed both for common crop yields and their management. This information can be easily provided by local technical advisors at the regional level (see for example [52]).

Finally, to model the yield of the new crop, a crop model is needed. In this case, the STICS model was used, however, several crop models have been parameterized in different world regions and can be used instead of STICS, as shown, for example, by [65] for spring barley. However, although these models are parameterized for the main crops, sometimes a few models are available to simulate yields for less common crops or for new or less common cultivars.

\section{Conclusions}

We have presented an innovative method to ex-ante assess the potential for a new crop at a regional level. The method was tested on the potential for soybean in the Oise region (Northern France) after the release to the market of new soybean maturity group varieties that can be grown in such areas. The suitability for soybean was assessed according to spatially-explicit pedo-climatic, agronomic and economic criteria. Spatial analysis and modelling were combined to explain the potential for soybean introduction in Oise crop-rotations. The proposed method is innovative in terms of previous land suitability studies, as it enhances the typical pedo-climatic-based studies by including agronomic rules for crop introduction in the ongoing crop rotations, and a spatially-explicit economic evaluation. It is also innovative in a context of poor references on the studied crop, as studies on yield gaps are unfeasible in the short term. The method and the references simulated can be used to support agro-food companies and cooperatives in strategic decision-making as well as farmers and advisors in the redesign of more sustainable cropping systems. In further studies, spatially-explicit models for crop rotation and the allocation of farming practices could also be implemented within the method in order to improve its reliability.

Author Contributions: Conceptualization, A.A.G. and E.M.; methodology, A.A.G., C.L., E.M. and O.S.; validation, A.A.G., C.L., E.M. and O.S.; formal analysis, A.A.G. and E.M.; investigation, A.A.G., C.L., E.M. and O.S.; resources, A.A.G., C.L., E.M. and O.S.; data curation, A.A.G. and E.M.; writing-original draft preparation, A.A.G. and E.M.; writing-review and editing, A.A.G., C.L., E.M. and O.S.; visualization, A.A.G. and E.M.; supervision, C.L.; project administration, A.A.G., C.L. and E.M. All authors have read and agreed to the published version of the manuscript.

Funding: This research received no external funding.

Acknowledgments: We greatly appreciate the hard work of the students: Azar Sara, Brancourt Juliette, Crignon Romain, Denormandie Claire, Du Reau Pierre-Emmanuel, Heinrich Pierre, Jugand Benoit, Lesure Anais, Meriaux Guillaume, Thulliez Caroline, Vandermeersch Elise, Vandewalle Anais, Vansteenberghe Alexis. Thanks also to our colleague Romain Armand for the useful discussions on LPIS database, the Oise Agricultural Chamber for the climatic data and useful discussions, Olivia Tavares from "AgroTransfert Ressources et Territoires" for exchanging the crop yield data parameterized in the PERSYST tool along with TERRES INOVIA for providing information on the climatic potential for soybean.

Conflicts of Interest: The authors declare no conflict of interest. 


\section{Appendix A}

Table A1. Main parameters used for soybean yield modelling with STICS.

\begin{tabular}{|c|c|c|c|c|c|c|c|c|}
\hline Soil Ttype & SiL-1 & SiL-c & SaL-1 & SaL-c & $\mathrm{CaL}$ & hSiL-1 & L-r & L-1 \\
\hline Main characteristics & Deep silt loam & $\begin{array}{c}\text { Moderately } \\
\text { deep silt loam }\end{array}$ & $\begin{array}{l}\text { Moderately } \\
\text { deep Sandy } \\
\text { loam }\end{array}$ & $\begin{array}{l}\text { Moderately } \\
\text { deep Sandy } \\
\text { loam }\end{array}$ & $\begin{array}{l}\text { Shallow } \\
\text { calcareous loam }\end{array}$ & $\begin{array}{l}\text { Moderately } \\
\text { deep silt loam } \\
\text { hydromorphic }\end{array}$ & $\begin{array}{c}\text { Deep loam/silt } \\
\text { loam }\end{array}$ & Deep loam \\
\hline $\begin{array}{l}\text { Reference soil group } \\
\text { (WRB) }\end{array}$ & luvisol & Cambisol & luvisol & cambisol & leptosol & luvisol & regosol & luvisol \\
\hline Argi * & 17 & 24 & 10 & 18 & 14 & 21 & 25 & 15 \\
\hline Norg & 0.12 & 0.12 & 0.12 & 0.12 & 0.12 & 0.12 & 0.12 & 0.12 \\
\hline Profhum & 35 & 35 & 35 & 35 & 35 & 35 & 35 & 35 \\
\hline Calc & 1 & 1 & 1 & 1 & 50 & 1 & 7 & 1 \\
\hline $\mathrm{pH}$ & 7 & 7 & 7 & 7 & 8 & 7 & 7 & 7 \\
\hline Albedo & 0.22 & 0.25 & 0.25 & 0.25 & 0.31 & 0.22 & 0.22 & 0.23 \\
\hline q0 & 8 & 9 & 7.5 & 8 & 9 & 9 & 9 & 7 \\
\hline Obstarac & 130 & 80 & 80 & 85 & 55 & 50 & 200 & 100 \\
\hline Zesx & 120 & 90 & 110 & 120 & 70 & 90 & 120 & 120 \\
\hline \multicolumn{9}{|l|}{ Epc } \\
\hline Horizon 1 & 30 & 25 & 30 & 35 & 30 & 30 & 30 & 35 \\
\hline Horizon 2 & 15 & 15 & 15 & 35 & 25 & 30 & 65 & 35 \\
\hline Horizon 3 & 20 & 20 & 35 & 15 & 0 & 0 & 30 & 30 \\
\hline Horizon 4 & 15 & 20 & 0 & 0 & 0 & 0 & 0 & 0 \\
\hline Horizon 5 & 50 & 0 & 0 & 0 & 0 & 0 & 0 & 0 \\
\hline \multicolumn{9}{|l|}{ HCCF } \\
\hline Horizon 1 & 23 & 24 & 15 & 19 & 25 & 24 & 24 & 20 \\
\hline Horizon 2 & 25.5 & 29.5 & 10.5 & 19 & 24 & 25.5 & 22.5 & 22.5 \\
\hline Horizon 3 & 25.5 & 24 & 10.5 & 19 & 0 & 0 & 22.5 & 19 \\
\hline Horizon 4 & 25.5 & 24 & 0 & 0 & 0 & 0 & 0 & 0 \\
\hline Horizon 5 & 25.5 & 0 & 0 & 0 & 0 & 0 & 0 & 0 \\
\hline \multicolumn{9}{|l|}{ HMINF } \\
\hline Horizon 1 & 10 & 12 & 5 & 10 & 10 & 12 & 12 & 8.9 \\
\hline Horizon 2 & 12.8 & 22 & 4 & 10 & 10 & 13 & 12 & 12.8 \\
\hline Horizon 3 & 12.8 & 10 & 4 & 10 & 0 & 0 & 12 & 10 \\
\hline Horizon 4 & 12.8 & 10 & 0 & 0 & 0 & 0 & 0 & 0 \\
\hline Horizon 5 & 12.8 & 0 & 0 & 0 & 0 & 0 & 0 & 0 \\
\hline
\end{tabular}


Table A1. Cont.

\begin{tabular}{|c|c|c|c|c|c|c|c|c|}
\hline Soil Ttype & SiL-1 & SiL-c & SaL-1 & SaL-c & $\mathrm{CaL}$ & hSiL-1 & L-r & L-1 \\
\hline \multicolumn{9}{|l|}{ DAF } \\
\hline Horizon 1 & 1.4 & 1.45 & 1.4 & 1.5 & 1.2 & 1.45 & 1.45 & 1.5 \\
\hline Horizon 2 & 1.5 & 1.45 & 1.5 & 1.6 & 1.25 & 1.5 & 1.55 & 1.55 \\
\hline Horizon 3 & 1.5 & 1.25 & 1.5 & 1.6 & 0 & 0 & 1.55 & 1.6 \\
\hline Horizon 4 & 1.5 & 1.25 & 0 & 0 & 0 & 0 & 0 & 0 \\
\hline Horizon 5 & 1.5 & 0 & 0 & 0 & 0 & 0 & 0 & 0 \\
\hline \multicolumn{9}{|l|}{ Cailloux } \\
\hline Horizon 1 & 0 & 3 & 2 & 0 & 2 & 0 & 3 & 0 \\
\hline Horizon 2 & 0 & 7 & 0 & 0 & 2 & 0 & 0 & 0 \\
\hline Horizon 3 & 0 & 30 & 0 & 0 & 0 & 0 & 0 & 0 \\
\hline Horizon 4 & 0 & 20 & 0 & 0 & 0 & 0 & 0 & 0 \\
\hline Horizon 5 & 0 & 35 & 0 & 0 & 0 & 0 & 0 & 0 \\
\hline
\end{tabular}

* Where Argi = Clay content after decarbonation; Norg = Soil organic N content in the first soil layer; Profhum = Maximum soil depth with an active biological activity; calc = Total carbonate content; $\mathrm{pH}=$ Initial soil $\mathrm{pH}$; albedo= albedo of the bare dry soil; $\mathrm{q} 0=$ cumulative soil evaporation above which evaporation rate is decreased; obstarac = soil depth at which root growth is stopped due to physical constraints; zesx = maximal soil depth affected by soil evaporation; epc $=$ thickness of each soil layer; HCCF $=$ gravimetric water content at field capacity of each soil layer; HMINF = gravimetric water content at wilting point of each soil layer; DAF = bulk density of fine earth fraction in each soil layer; Cailloux = volumetrix content of pebbles per soil layer. Some parameters were identical for all soil types: The fraction of runoff in a bare soil: ruisolnu $=0$. The minimal amount of water required to create a soil crust: pluibat $=50 \mathrm{~mm}$. $\mathrm{d}-1$. The mulch depth which a crust occurs: mulchbat $=0.5 \mathrm{~cm}$. The parameter defining the soil contribution to evaporation versus depth: cfes $=5$. The minimum concentration of $\mathrm{HNO} 3$ in soil: concseuil $=0$. The roughness length of bare soil: $z 0$ solnu $=0.01 \mathrm{~m}$. The initial $\mathrm{C}$ to $\mathrm{N}$ ratio on soil humus: CsurNsol $=0$. The runoff coefficient taking account for plant mulch: penterui $=0.33$. With no: pebbles, macroporosity, cracks, artificial drainage, capillary rise, nitrification and denitrification. 


\section{References}

1. Wezel, A.; Casagrande, M.; Celette, F.; Vian, J.F.; Ferrer, A.; Peigné, J. Agroecological practices for sustainable agriculture. A review. Agron. Sustain. Dev. 2014, 34, 1-20. [CrossRef]

2. Bowen, C.R.; Hollinger, S.E. Geographic screening of potential alternative crops. Renew. Agric. Food Syst. 2004, 19, 141-151. [CrossRef]

3. Isbell, F.; Adler, P.R.; Eisenhauer, N.; Fornara, D.; Kimmel, K.; Kremen, C.; Letourneau, D.K.; Liebman, M.; Polley, H.W.; Quijas, S.; et al. Benefits of increasing plant diversity in sustainable agroecosystems. J. Ecol. 2017, 105, 871-879. [CrossRef]

4. Maaz, T.; Wulfhorst, J.D.; McCracken, V.; Kirkegaard, J.; Huggins, D.R.; Roth, I.; Kaur, H.; Pan, W. Economic, policy, and social trends and challenges of introducing oilseed and pulse crops into dryland wheat cropping systems. Agric. Ecosyst. Environ. 2018, 253, 177-194. [CrossRef]

5. European Commission. Development of Plant Proteins in the European Union; Commission to the Council and The European Parliament: Brussels, Belgium, 2018; p. 16.

6. Louhichi, K.; Ciaian, P.; Espinosa, M.; Colen, L.; Perni, A.; Paloma, S.G. Does the crop diversification measure impact EU farmers' decisions? An assessment using an Individual Farm Model for CAP Analysis (IFM-CAP). Land Use Policy 2017, 66, 250-264. [CrossRef]

7. Meynard, J.-M.; Messéan, A.; Charlier, F.; Charrier, M.; Farès, M.; Le Bail, M.; Magrini, M.-B.; Savini, I. Crop Diversification: Obstacles and Levers Study of Farms and Supply Chains; Synopsis of the study report; INRA: Paris, France, 2013.

8. Leclère, M.; Loyce, C.; Jeuffroy, M.-H. Growing camelina as a second crop in France: A participatory design approach to produce actionable knowledge. Eur. J. Agron. 2018, 101, 78-89. [CrossRef]

9. Rossiter, D.G. A theoretical framework for land evaluation. Geoderma 1996, 72, 165-190. [CrossRef]

10. Sillero, N. What does ecological modelling model? A proposed classification of ecological niche models based on their underlying methods. Ecol. Model. 2011, 222, 1343-1346. [CrossRef]

11. Rhebergen, T.; Fairhurst, T.; Zingore, S.; Fisher, M.; Oberthür, T.; Whitbread, A. Climate, soil and land-use based land suitability evaluation for oil palm production in Ghana. Eur. J. Agron. 2016, 81, 1-14. [CrossRef]

12. Soltani, A.; Stoorvogel, J.J.; Veldkamp, A. Model suitability to assess regional potato yield patterns in northern Ecuador. Eur. J. Agron. 2013, 48, 101-108. [CrossRef]

13. Ma, D.; Stützel, H. Prediction of winter wheat cultivar performance in Germany: At national, regional and location scale. Eur. J. Agron. 2014, 52, 210-217. [CrossRef]

14. Daccache, A.; Keay, C.; Jones, R.J.A.; Weatherhead, E.K.; Stalham, M.A.; Knox, J.W. Climate change and land suitability for potato production in England and Wales: Impacts and adaptation. J. Agric. Sci. 2012, 150, 161-177. [CrossRef]

15. Shabani, F.; Kumar, L.; Taylor, S. Suitable regions for date palm cultivation in Iran are predicted to increase substantially under future climate change scenarios. J. Agric. Sci. 2014, 152, 543-557. [CrossRef]

16. Geerts, S.; Raes, D.; Garcia, M.; Del Castillo, C.; Buytaert, W. Agro-climatic suitability mapping for crop production in the Bolivian Altiplano: A case study for quinoa. Agric. For. Meteorol. 2006, 139, $399-412$. [CrossRef]

17. Mendas, A.; Delali, A. Integration of MultiCriteria Decision Analysis in GIS to develop land suitability for agriculture: Application to durum wheat cultivation in the region of Mleta in Algeria. Comput. Electron. Agric. 2012, 83, 117-126. [CrossRef]

18. Ragaglini, G.; Triana, F.; Villani, R.; Bonari, E. Can sunflower provide biofuel for inland demand? An integrated assessment of sustainability at regional scale. Energy 2011, 36, 2111-2118. [CrossRef]

19. Ziadat, F.M.; Sultan, K.A. Combining current land use and farmers' knowledge to design land-use requirements and improve land suitability evaluation. Renew. Agric. Food Syst. 2011, 26, 287-296. [CrossRef]

20. Debolini, M.; Marraccini, E.; Rizzo, D.; Galli, M.; Bonari, E. Mapping local spatial knowledge in the assessment of agricultural systems: A case study on the provision of agricultural services. Appl. Geogr. 2013, 42, $23-33$. [CrossRef]

21. Aubry, C.; Papy, F.; Capillon, A. Modelling decision-making processes for annual crop management. Agric. Syst. 1998, 56, 45-65. [CrossRef] 
22. Castellazzi, M.S.; Wood, G.A.; Burgess, P.J.; Morris, J.; Conrad, K.F.; Perry, J.N. A systematic representation of crop rotations. Agric. Syst. 2008, 97, 26-33. [CrossRef]

23. Doré, T. L'assolement: Acception et problématiques agronomiques actuelles. Agron. Environ. Sociétés 2012, 2, 17-28.

24. Chopin, P.; Blazy, J.-M.; Doré, T. A new method to assess farming system evolution at the landscape scale. Agron. Sustain. Dev. 2015, 35, 325-337. [CrossRef]

25. Levavasseur, F.; Martin, P.; Bouty, C.; Barbottin, A.; Bretagnolle, V.; Thérond, O.; Scheurer, O.; Piskiewicz, N. RPG Explorer: A new tool to ease the analysis of agricultural landscape dynamics with the Land Parcel Identification System. Comput. Electron. Agric. 2016, 127, 541-552. [CrossRef]

26. Murgue, C.; Therond, O.; Leenhardt, D. Hybridizing local and generic information to model cropping system spatial distribution in an agricultural landscape. Land Use Policy 2016, 54, 339-354. [CrossRef]

27. Barbottin, A.; Bouty, C.; Martin, P. Using the French LPIS database to highlight farm area dynamics: The case study of the Niort Plain. Land Use Policy 2018, 73, 281-289. [CrossRef]

28. Sagris, V.; Wojda, P.; Milenov, P.; Devos, W. The harmonised data model for assessing Land Parcel Identification Systems compliance with requirements of direct aid and agri-environmental schemes of the CAP. J. Environ. Manag. 2013, 118, 40-48. [CrossRef]

29. Leteinturier, B.; Herman, J.L.; Longueville, F.; de Quintin, L.; Oger, R. Adaptation of a crop sequence indicator based on a land parcel management system. Agric. Ecosyst. Environ. 2006, 112, 324-334. [CrossRef]

30. Xiao, Y.; Mignolet, C.; Mari, J.-F.; Benoît, M. Modeling the spatial distribution of crop sequences at a large regional scale using land-cover survey data: A case from France. Comput. Electron. Agric. 2014, 102, 51-63. [CrossRef]

31. Metzger, M.J.; Bunce, R.G.H.; Jongman, R.H.G.; Mücher, C.A.; Watkins, J.W. A climatic stratification of the environment of Europe. Glob. Ecol. Biogeogr. 2005, 14, 549-563. [CrossRef]

32. CA Oise. Présentation Des Systèmes D'exploitation Agricole De Picardie; Chambre d'Agriculture de l'Oise: Beauvais, France, 2010; p. 436.

33. Plan Ecophyto II; Ministère de L'Agriculture et de L'Alimentation: Paris, France, 2015; p. 67.

34. Agreste. Memento De La Statistique Agricole. Direction Régionale De L'Alimentation, De L'Agriculture Et De La Forêt; Service Régional de L'Information Statistique Et Economique: Paris, France, 2016; p. 26.

35. Terres Inovia. Synthèse Soja Réseau Terres Inovia; Résultats Des Variétés Issues Du Catalogue Français: Paris, France, 2016; p. 5.

36. Ku, Y.S.; Au-Yeung, W.K.; Ying, Y.L.; Li, M.W.; Wen, C.Q.; Liu, X.; Lam, H.M. Drought stress and tolerance in soybean. In A Comprehensive Survey of International Soybean Research-Genetics, Physiology, Agronomy and Nitrogen Relationships; James, E., Ed.; IntechOpen: London, UK, 2013; pp. 209-238. [CrossRef]

37. Sentelhas, P.C.; Battisti, R.; Câmara, G.M.S.; Farias, J.R.B.; Hampf, A.C.; Nendel, C. The soybean yield gap in Brazil-Magnitude, causes and possible solutions for sustainable production. J. Agric. Sci. 2015, 153, 1394-1411. [CrossRef]

38. Aper, J.; De Clercq, H.; Baert, J. Agronomic characteristics of early-maturing soybean and implications for breeding in Belgium. Plant Genet. Resour. 2016, 14, 142-148. [CrossRef]

39. King, D.; Stengel, P.; Jamagne, M.; Le Bas, C.; Arrouays, D. Soil Mapping and Soil Monitoring: State of Progress and Use in France; Jones, Ed.; Soil Resources of Europe, European Soil Bureau, Institute of Environmental Sustainability, JRC: Ispra, Italy, 2005; p. 433.

40. Arrouays, D.; Hardy, R.; Schnebelen, N.; Le Bas, C.; Eimberck, M.; Roque, J.; Grolleau, E.; Pelletier, A.; Doux, J.; Lehmann, S.; et al. Le programme Inventaire Gestion et Conservation des Sols de France. Etude Gest. Sols 2004, 11, 187-197.

41. Inskeep, W.; Bloom, P.R. Effects of Soil Moisture on Soil pCO2, Soil Solution Bicarbonate, and Iron Chlorosis in Soybeans 1. SSSAJ 1986, 50, 946-952. [CrossRef]

42. Rodrigues, T.R.; Casaroli, D.; Evangelista, A.W.P.; Alves Júnior, J. Water availability to soybean crop as a function of the least limiting water range and evapotranspiration1. Pesqui. Agropecuária Trop. 2017, 47, 161-167. [CrossRef]

43. Oosterhuis, D.M.; Scott, H.D.; Hampton, R.E.; Wullschleger, S.D. Physiological responses of two soybean [Glycine max (L.) Merr] cultivars to short-term flooding. Environ. Exp. Bot. 1990, 30, 85-92. [CrossRef]

44. EEA. Corine Land Cover Technical Guidelines; European Environmental Agency: Copenhagen, Denmark, 2007. 
45. Zimmermann, J.; González, A.; Jones, M.B.; O’Brien, P.; Stout, J.C.; Green, S. Assessing land-use history for reporting on cropland dynamics-A comparison between the Land-Parcel Identification System and traditional inter-annual approaches. Land Use Policy 2016, 52, 30-40. [CrossRef]

46. Brisson, N.; Mary, B.; Ripoche, D.; Jeuffroy, M.H.; Ruget, F.; Nicoullaud, B.; Gate, P.; Devienne-Barret, F.; Antonioletti, R.; Durr, C.; et al. STICS: A generic model for the simulation of crops and their water and nitrogen balances. I. Theory and parameterization applied to wheat and corn. Agronomie 1998, 18, 311-346. [CrossRef]

47. Brisson, N.; Ruget, F.; Gate, P.; Lorgeou, J.; Nicoullaud, B.; Tayot, X.; Plenet, D.; Jeuffroy, M.-H.; Bouthier, A.; Ripoche, D.; et al. STICS: A generic model for simulating crops and their water and nitrogen balances. II. Model validation for wheat and maize. Agronomie 2002, 22, 69-92. [CrossRef]

48. Jégo, G.; Pattey, E.; Bourgeois, G.; Morrison, M.J.; Drury, C.F.; Tremblay, N.; Tremblay, G. Calibration and performance evaluation of soybean and spring wheat cultivars using the STICS crop model in Eastern Canada. Field Crop. Res. 2010, 117, 183-196. [CrossRef]

49. Guichard, L.; Bockstaller, C.; Loyce, C.; Makowski, D. PERSYST, a cropping system model based on local expert knowledge. In Proceedings of the Agro 2010 the XIth ESA Congress; Wery, J., Shili-Touzi, I., Perrin, A., Eds.; Agropolis International Editions: Motpellier, France, 2010; pp. 827-828.

50. Arvalis-Institut du végétal. UNIP Pois. In Quoi De Neuf Protéagineux; Editions Arvalis: Flers, France, 2012; pp. 56-62.

51. Rieu, C.; Doucet, R.; Seguin, B.; Jouy, L.; Vacher, C.; Bordes, J.P.; Viaux, P. Blé sur blé: Techniques et enjeux. Perspect. Agric. 2000, 258, 26-31.

52. CA Oise. Assolement \& Stratégie, Récolte 2015; Chambre d'Agriculture de l'Oise: Beauvais, France, $2015 ;$ p. 22.

53. COMIFER. Calcul de la Fertilisation Azotée-Guide Méthodologique Pour L'établissement Des Prescriptions Locales. Cultures Annuelles et Prairies; COMité Français d'Etude et de développement de la FERtilisation raisonnée: Paris, France, 2013; p. 159.

54. Ansel, O.; Epinat, V.; Scheurer, O. Guide Agronomique Des Sols Du Département De L'Oise. ISAB/Conseil Général De L'Oise/Chambre d'Agriculture de l'Oise. Available online: http://www.chambres-agriculture-picardie.fr/menus-horizontaux/oise/la-chambre-dagriculture-deloise/outils-pratiques/guide-des-sols.html (accessed on 16 December 2019).

55. Peregrine, E.K.; Sprau, G.L.; Cremeens, C.R.; Nelson, R.L.; Orf, J.H.; Thomas, D.A. Evaluation of the USDA Soybean Germplasm Collection: Maturity Groups 000-IV (PI 578371-PI612761); Technical Bulletin; U.S. Department of Agriculture: Washington, DC, USA, 2008; p. 155.

56. Benoît, M.; Rizzo, D.; Marraccini, E.; Moonen, A.C.; Galli, M.; Lardon, S.; Rapey, H.; Thenail, C.; Bonari, E. Landscape agronomy: A new field for addressing agricultural landscape dynamics. Landsc. Ecol. 2012, 27, 1385-1394. [CrossRef]

57. Castellazzi, M.S.; Matthews, J.; Angevin, F.; Sausse, C.; Wood, G.A.; Burgess, P.J.; Brown, I.; Conrad, K.F.; Perry, J.N. Simulation scenarios of spatio-temporal arrangement of crops at the landscape scale. Environ. Model. Softw. 2010, 25, 1881-1889. [CrossRef]

58. Voisin, A.-S.; Guéguen, J.; Huyghe, C.; Jeuffroy, M.-H.; Magrini, M.-B.; Meynard, J.-M.; Mougel, C.; Pellerin, S.; Pelzer, E. Legumes for feed, food, biomaterials and bioenergy in Europe: A review. Agron. Sustain. Dev. 2014, 34, 361-380. [CrossRef]

59. Zander, P.; Amjath-Babu, T.S.; Preissel, S.; Reckling, M.; Bues, A.; Schläfke, N.; Kuhlman, T.; Bachinger, J.; Uthes, S.; Stoddard, F; et al. Grain legume decline and potential recovery in European agriculture: A review. Agron. Sustain. Dev. 2016, 36, 26. [CrossRef]

60. Magrini, M.-B.; Anton, M.; Cholez, C.; Corre-Hellou, G.; Duc, G.; Jeuffroy, M.-H.; Meynard, J.-M.; Pelzer, E.; Voisin, A.-S.; Walrand, S. Why are grain-legumes rarely present in cropping systems despite their environmental and nutritional benefits? Analyzing lock-in in the French agrifood system. Ecol. Econ. 2016, 126, 152-162. [CrossRef]

61. Zimdahl, R.L. Fundamentals of Weed Science, 3rd ed.; Elsevier: Amsterdam, The Netherlands, 2007; ISBN 978-0-12-372518-9. 
62. Boulch, G.; Djemel, A.; Lange, B. Evaluation of the Potential Adaptation of Soybean (Glycine Max L.) to Northern France Using Crop Modeling Simulations. In Proceedings of the ICROPM2020-Crop Modelling for the Future. Book of Abstract, Second International Crop Modelling Symposium, Montpellier, France, 3-5 February 2020; pp. 371-372. Available online: https:/www.alphavisa.com/icropm/2020/documents/ iCROPM2020-Book-of-Abstracts.pdf (accessed on 19 February 2020).

63. Boettinger, J.; Howell, D.; Moore, A.; Hartemink, A.; Kienast-brown, S. Digital Soil Mapping: Bridging Research, Environmental Application, and Operation; Springer: Dordrecht, The Netherlands; Heidelberg, Germany; London, UK; New York, NY, USA, 2010.

64. Martínez-Casasnovas, J.A.; Martín-Montero, A.; Auxiliadora Casterad, M. Mapping multi-year cropping patterns in small irrigation districts from time-series analysis of Landsat TM images. Eur. J. Agron. 2005, 23, 159-169. [CrossRef]

65. Rötter, R.P.; Palosuo, T.; Kersebaum, K.C.; Angulo, C.; Bindi, M.; Ewert, F.; Ferrise, R.; Hlavinka, P.; Moriondo, M.; Nendel, C.; et al. Simulation of spring barley yield in different climatic zones of Northern and Central Europe: A comparison of nine crop models. Field Crop. Res. 2012, 133, 23-36. [CrossRef]

(C) 2020 by the authors. Licensee MDPI, Basel, Switzerland. This article is an open access article distributed under the terms and conditions of the Creative Commons Attribution (CC BY) license (http://creativecommons.org/licenses/by/4.0/). 